\title{
30. PLEISTOCENE CLIMATIC CHANGES IN SURFACE WATERS OF THE NORTHEASTERN ATLANTIC: OXYGEN AND CARBON ISOTOPIC COMPOSITIONS OF PLANKTONIC FORAMINIFERS AT DEEP SEA DRILLING PROJECT SITES 548 AND 5491
}

\author{
C. Vergnaud Grazzini and J. F. Saliège, Département de Géologie Dynamique²
}

\begin{abstract}
Oxygen- and carbon-isotope analyses have been performed on the Quaternary planktonic foraminifers of Sites 548 and 549 (DSDP Leg 80) to investigate major water mass changes that occurred in the northeastern Atlantic at different glacial-interglacial cycles and to compare them with the well-defined picture of $18,000 \mathrm{yr}$. ago. Oxygen-isotope stratigraphy also provides a chronological framework for the more important data on the fauna and flora. Although bioturbation and sedimentary gaps obliterate the climatic and stratigraphic record, general trends in the oceanographic history can be deduced from the isotopic data. Isotopic stratigraphy has tentatively been delineated down to isotopic Stage 16 at Site 548 and in Hole 549A. This stratigraphy fits well with that deduced from benthic foraminiferal $\delta^{18} \mathrm{O}$ changes and with bioclimatic zonations based on foraminiferal associations at Site 549. Variations in the geographic extension and in the flux of the Gulf Stream subtropical waters are inferred from both $\delta^{18} \mathrm{O}$ and $\delta^{13} \mathrm{C}$ changes. Maximal fluxes occurred during the late Pliocene. Northward extension of subtropical waters increased through the various interglacial phases of the early Pleistocene and decreased through the late Pleistocene interglacial phases. Conversely, glacial maxima were more intense after Stage 16. Isotopic Stages 12 and 16 mark times of important change in water mass circulation.
\end{abstract}

\section{INTRODUCTION}

Oxygen- and carbon-isotope analyses have been conducted on planktonic foraminifers from Pleistocene sediments recovered from Holes 548 and 549A (DSDP Leg 80) on Goban Spur (see Fig. 1).

\begin{tabular}{lcccc}
\hline Holes & $\begin{array}{c}\text { Latitude } \\
(\mathrm{N})\end{array}$ & $\begin{array}{c}\text { Longitude } \\
(\mathrm{W})\end{array}$ & $\begin{array}{c}\text { Water depth } \\
(\mathrm{m})\end{array}$ & $\begin{array}{c}\text { Number of } \\
\text { samples }\end{array}$ \\
\hline 548 & $48^{\circ} 54^{\prime} 95$ & $12^{\circ} 09^{\prime} 84$ & 1256.0 & 135 \\
$549 \mathrm{~A}$ & $49^{\circ} 05^{\prime} 23$ & $1^{\circ} 05^{\prime} 89$ & 2535.5 & 58 \\
\hline
\end{tabular}

During the last glacial stage, this region underwent important hydrological changes resulting from movement of the polar front and the subarctic convergence. At times these sites were located north of the polar front and/or the subarctic convergence, which at 18,000 and $10,200 \mathrm{yr}$. ago, for instance, were located at $42^{\circ} \mathrm{N}(\mathrm{Pu}-$ jol, 1980). At those times the North Atlantic drift was not able to penetrate this eastern region of the Atlantic. Thus, surface circulation at these sites might have been, alternately, a cyclonic gyre $(18,000$ yr. ago, with very different summer and winter temperatures) and an anticyclonic gyre (present-day situation).

Furthermore, some authors have suggested that during the last deglaciation (mainly between 16,000 and 8,000 yr. ago), low-salinity waters formed a lid in that region (Jones and Ruddiman, 1982). If so, this should be recorded in deep-sea sediments of that age.

\footnotetext{
${ }^{1}$ Graciansky, P. C. de, Poag, C. W., et al., Init. Repts. DSDP, 80: Washington (U.S. Govt, Printing Office). France.
}

Thus, the now well-documented picture of the most recent glaciation in the northeastern Atlantic can be compared with conditions during older glaciations, as deduced from the oxygen-isotope record in planktonic foraminifers.

In addition, variations in the carbon isotopic composition of planktonic foraminifers may provide some information about similar variations in the $\mathrm{CO}_{2}$ of the atmospheric reservoir and about the latitudinal extension of warm subtropical water masses. Present-day total dissolved inorganic carbon has higher $\delta^{13} \mathrm{C}$ values in warm equatorial and tropical waters. At these low latitudes, the temperature causes a departure of isotopically light $\mathrm{CO}_{2}$; as a result, the $\delta^{13} \mathrm{C}$ of the remaining $\Sigma \mathrm{CO}_{2}$ increases: the lower the $\mathrm{CO}_{2}$ concentration, the higher its $\delta^{13} \mathrm{C}$ value.

\section{PRESENT-DAY HYDROLOGICAL FRAMEWORK}

Circulation at high latitudes in the North Atlantic is dominated by a subpolar gyral system that flows counterclockwise and opposite in direction to the central gyral system. This circulatory system is illustrated in Figure 1 .

On the eastern side of the subpolar gyre there is a sharp boundary between adjacent warm and cold water masses. It is identified by the $10^{\circ}$ isotherm at $200 \mathrm{~m}$. This boundary corresponds to the polar front in the atmosphere and also to the subarctic convergence in the ocean. It has a distinctly north-south trend but follows a sinuous path. On the eastern side of the polar front and the subpolar gyre is the north-flowing North Atlantic Current bearing waters of subtropical origin, and on the western side is the south-flowing Labrador Current bearing waters of subpolar origin.

Therefore, in the North Atlantic, water-mass boundaries are not parallel with latitude, in contrast to the 


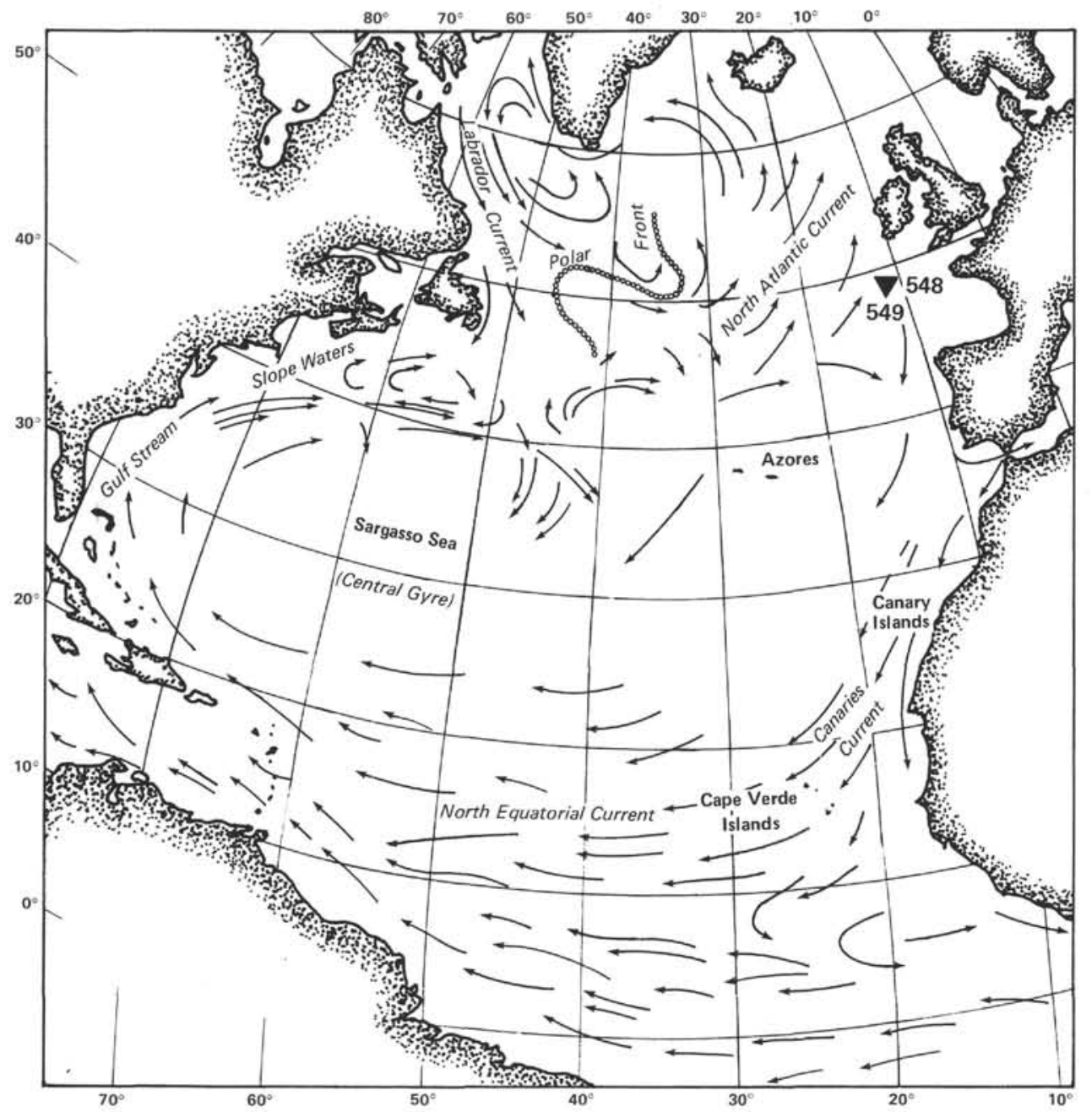

Figure 1. The major features of North Atlantic circulation and location of Sites 548 and 549.

South Atlantic where (at least at high latitudes) the parallel is very close. Thus, in the North Atlantic, boundaries between planktonic foraminiferal assemblages may be expected to have stronger tendencies to follow the meridians (Cifelli and McCloy, 1983). Present-day assemblages at the location of Sites 548 and 549 are dominated by species characteristic of subpolar waters, such as right-coiling Neogloboquadrina pachyderma (with present-day percentages $\geq 80 \%$ ), while arctic assemblages dominated by left-coiling $N$. pachyderma are present west of the polar front and in the Norwegian sea. Glacial-interglacial changes that terminated each glacial cycle (called terminations by Broecker and van Donk, 1970) at these latitudes, when accompanied by a sudden shift of the Polar Front and the subarctic convergence, should also be characterized by the replacement of a predominantly polar fauna $(\sim 100 \%$ of left-coiling $N$. pachyderma) with a mixed subpolar-transitional assemblage (Ruddiman and McIntyre, 1976). Thus, fossil assemblages for glacial times analogous to $18,000 \mathrm{yr}$. ago should also be characterized by dominance of left-coiling $N$. pachyderma in planktonic foraminiferal assemblages (Fig. 2).
At the location of Sites 548 and 549 , salinity is about $35.5 \%$ in surface waters. $\delta^{13} \mathrm{C}$ values of the total dissolved inorganic carbon range from $+1.6 \%$ to $+1.9 \%$ (Duplessy, 1972); $\delta^{18} \mathrm{O}$ values are about $\pm 0.2 \%$ on the SMOW scale. Summer temperatures are about $17^{\circ} \mathrm{C}$ and winter temperatures about $10^{\circ} \mathrm{C}$.

\section{STABLE-ISOTOPE RESULTS}

The planktonic foraminifers Globigerina bulloides and, at some levels, Neogloboquadrina pachyderma were picked. Stable-isotopic analyses were made following the procedure described by the authors in their other chapter in this volume. Benthic foraminifers have been analyzed by the same authors (this volume). Results are reported in Table 1 for Hole 548 and Table 2 for Hole 549A and plotted against sub-bottom depth in Figure 3 (548) and Figure 4 (549A). N. pachyderma $\delta^{18} \mathrm{O}$ values differ from those of $G$. bulloides, but the amplitude of the oxygen-isotope fractionation between the species is not well established. On the contrary, the carbon-isotope fractionation is similar for both species in the Indian Ocean (Williams et al., 1977), which is assumed here to be the case for the Atlantic as well. 
A
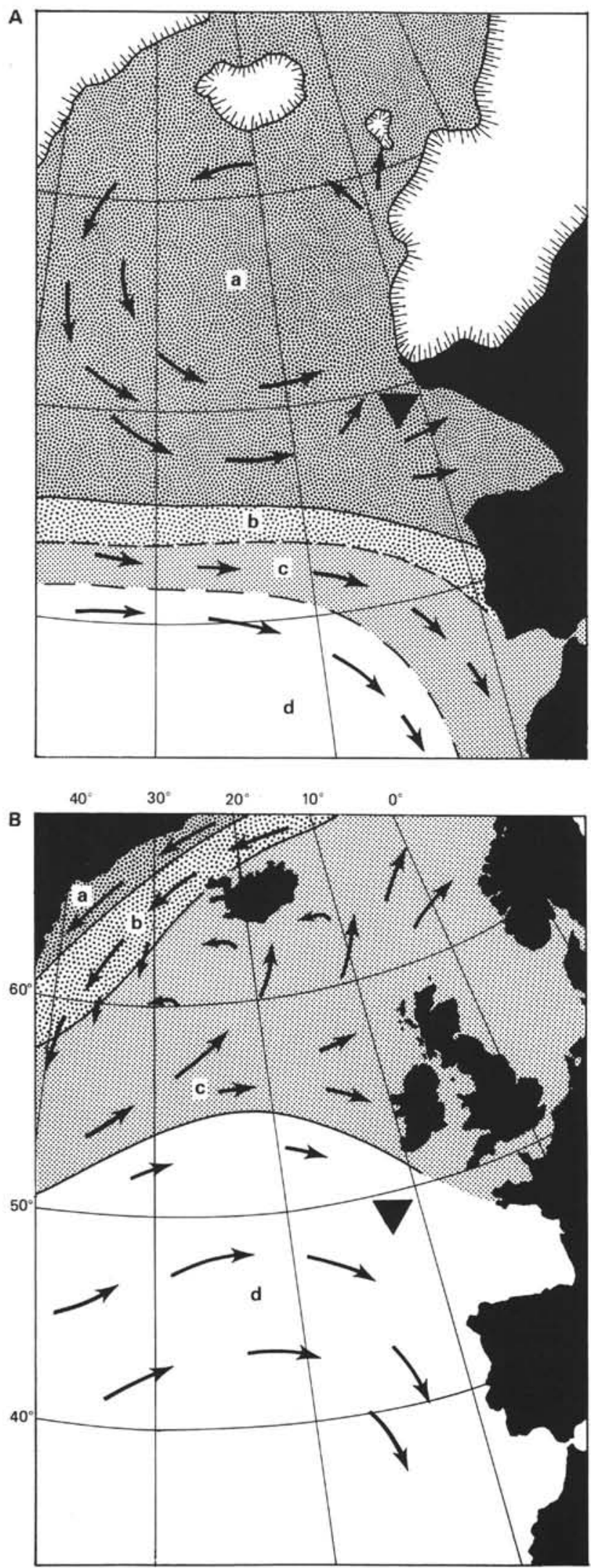

Figure 2. Water masses in the northeastern Atlantic 18,000 years ago (A) and for warm interglacial stages similar to 125,000 years ago (B), extrapolated from Ruddiman and McIntyre (1976). $\mathrm{a}=$ polar waters; $\mathrm{b}=$ subpolar waters; $\mathrm{c}=$ transitional waters; $\mathrm{d}=$ subtropical waters.
Table 1. Oxygen- and carbon-isotope analysis (\%o) of G. bulloides and/or $N$. pachyderma from Hole 548 .

\begin{tabular}{|c|c|c|c|c|c|c|c|}
\hline $\begin{array}{l}\text { Depth below } \\
\text { seafloor } \\
\text { (m) }\end{array}$ & $\begin{array}{l}\text { Core-Section } \\
\text { (level in } \mathrm{cm})\end{array}$ & ${ }^{18} \mathrm{O}^{\mathrm{a}}$ & ${ }_{8}^{13} \mathrm{C}^{\mathrm{a}}$ & $\begin{array}{l}\text { Depth below } \\
\text { seafloor } \\
\text { (m) }\end{array}$ & $\begin{array}{l}\text { Core-Section } \\
\text { (level in } \mathrm{cm} \text { ) }\end{array}$ & $8^{18} \mathrm{O}$ & ${ }^{13} \mathrm{C}$ \\
\hline & $1-1,4$ & +2.21 & -0.37 & & $11-1,73$ & +1.27 & -1.16 \\
\hline & $1-1,14$ & +1.28 & -0.77 & & $11-1,140$ & +1.45 & -1.39 \\
\hline & $1-1,70$ & +1.40 & -1.50 & & $11-2,140$ & +1.91 & - \\
\hline & $1-2,90^{b}$ & +3.20 & -0.17 & & $11-3,50^{6}$ & +1.23 & -1.19 \\
\hline \multirow[t]{14}{*}{4.0} & $1-3,20^{b}$ & +2.65 & -0.56 & & $11-4,50^{b}$ & +1.43 & -1.10 \\
\hline & & & & & $11-4,140$ & +0.50 & -1.10 \\
\hline & $2-1,20$ & +3.33 & -1.17 & & $11-5,17$ & +1.38 & -0.68 \\
\hline & $2-1,41$ & +2.45 & -1.00 & & $11-5,50$ & +1.21 & -0.95 \\
\hline & & & & & $11-6,8$ & +1.07 & -0.83 \\
\hline & $2-2,20$ & +1.19 & -1.42 & & & & \\
\hline & $2-2,130$ & +2.10 & -0.61 & 93.3 & $13-1,130$ & +1.34 & -0.24 \\
\hline & $2-3,20$ & +3.27 & -0.72 & & $13-2,35$ & +0.63 & -1.37 \\
\hline & $2-4,33$ & +2.44 & -0.87 & & $13-2,120$ & +1.42 & -0.87 \\
\hline & $2-4,50$ & +3.34 & -0.40 & & $13-2,137$ & +2.00 & -0.73 \\
\hline & $2-4,153$ & +2.21 & -0.39 & & $13-3,22$ & +1.91 & +0.03 \\
\hline & $2-5,2$ & +2.46 & -0.90 & & $13-3,105$ & +1.87 & -0.77 \\
\hline & $2-5,33$ & +2.33 & -0.90 & & $13-3,130$ & +1.50 & -0.94 \\
\hline & $2-6,33$ & +2.30 & -0.46 & & $13-4,35$ & +1.05 & -0.35 \\
\hline \multirow[t]{11}{*}{13.5} & $2-7,33$ & +1.77 & -0.93 & & $13-4,95$ & +1.58 & -0.86 \\
\hline & & & & & $13-5,35$ & +1.08 & -0.86 \\
\hline & $3-1,34$ & +3.03 & -0.99 & & $13-6,27$ & +1.85 & -0.42 \\
\hline & $3-1,56$ & +1.62 & -0.45 & & & & \\
\hline & $3-1,76$ & +1.70 & -0.25 & & $14-1,4$ & +1.56 & -0.66 \\
\hline & $3-1,116$ & +1.46 & -0.81 & 99.4 & $14-1,40$ & +1.73 & -0.53 \\
\hline & $3-2,76$ & +1.61 & -0.44 & & $14-2,84$ & +1.97 & +0.08 \\
\hline & $3-3,76$ & +2.16 & -1.35 & & & & \\
\hline & $3-4,76$ & +1.34 & -1.53 & 101.1 & $15 \cdot 1,112$ & +1.73 & -1.33 \\
\hline & $3-6,75^{b}$ & +3.16 & -0.44 & & $15-2,30$ & +1.89 & -0.46 \\
\hline & $3-7,29^{b}$ & +3.46 & -0.52 & & $15-2,112$ & +1.63 & -0.93 \\
\hline \multirow[t]{20}{*}{23.0} & & & & & $15-3,30$ & +1.87 & -1.08 \\
\hline & $4-1,61$ & +2.17 & -0.74 & & $15-3,110$ & +1.52 & -1.42 \\
\hline & $4-2,61$ & +1.09 & -0.95 & & $15-4,3$ & +2.81 & -0.60 \\
\hline & $4-3,61$ & +1.83 & -0.96 & & $15-4,12$ & +1.73 & -1.09 \\
\hline & $4-4,61$ & +1.95 & -0.97 & & $15-4,27$ & +1.71 & -1.10 \\
\hline & $4-5,61$ & +2.40 & - & & $15-4,110$ & +2.47 & -0.50 \\
\hline & & & & & $15-5,30$ & +1.93 & -0.41 \\
\hline & $5-1,73$ & +1.20 & -1.07 & 106.6 & $15-5,63$ & +1.88 & -0.21 \\
\hline & $5-2,21$ & +1.24 & -0.71 & & $15-5,92$ & +2.64 & -0.08 \\
\hline & $5-2,77$ & +1.36 & -0.46 & & $15-5,130$ & +2.11 & 0.00 \\
\hline & $5-4,21$ & +1.70 & -0.70 & & $15-6,120$ & +1.25 & -0.91 \\
\hline & $6-1,57$ & +2.10 & -1.08 & & $16-1,70$ & +1.36 & -0.86 \\
\hline & $6-2,16$ & +1.84 & -0.67 & & $16-2,140$ & +1.07 & -0.72 \\
\hline & $7-2,84^{\mathrm{b}}$ & +1.61 & -1.57 & & $16-3,50$ & +1.45 & -1.11 \\
\hline & $7 \cdot 3,40^{b}$ & +2.50 & -1.40 & & $16-4,70$ & +1.15 & -0.42 \\
\hline & $7-3,104$ & +2.40 & - & & $16-5,70$ & +1.14 & -0.19 \\
\hline & $7-5,19$ & +2.13 & -1.11 & 118.0 & & & \\
\hline & $7-5,140$ & +2.30 & -1.44 & & $17-1,53$ & +1.60 & +0.13 \\
\hline & $7-6,40$ & +1.18 & -0.77 & & $17-1,113$ & +1.64 & +0.12 \\
\hline & $7-6,110$ & +1.06 & -0.43 & & $17-2,80$ & +2.01 & +0.40 \\
\hline \multirow[t]{9}{*}{61.0} & $7-7,10$ & +1.30 & -0.99 & & $17-2,105$ & +1.00 & +0.37 \\
\hline & & & & & $17-3,103$ & +1.78 & +0.26 \\
\hline & $8 \cdot 1,69$ & +1.83 & -0.35 & & $17-4,100$ & +1.14 & -0.32 \\
\hline & $8-1,123$ & +1.57 & -0.08 & & $17-5,50$ & +2.53 & -0.26 \\
\hline & $8-2,40$ & +0.87 & -0.66 & 126.0 & & & \\
\hline & $8-2,90$ & +1.47 & -0.66 & & $18-1,102$ & +1.48 & -0.30 \\
\hline & $8-4,20$ & +1.03 & -0.94 & & $18-3,42$ & +1.30 & -0.19 \\
\hline & $8-5,103$ & +2.06 & -1.15 & & $18-3,99$ & +1.93 & +0.05 \\
\hline & $8-6,69$ & +1.34 & -0.81 & & $18-4,22$ & +1.70 & +0.27 \\
\hline \multirow[t]{7}{*}{70.5} & $8-6,124$ & +1.65 & -0.85 & 131.0 & & & \\
\hline & & & & & $19-1,73$ & +1.56 & +0.60 \\
\hline & $9-1,120$ & +0.83 & -1.09 & & $19-1,77$ & +1.85 & +0.37 \\
\hline & $9-1,100$ & +0.80 & -1.49 & & $19-2,70$ & +1.53 & -0.02 \\
\hline & $9-2,20$ & +0.75 & -1.22 & & $19-2,94$ & +1.38 & +0.61 \\
\hline & $9-2,43$ & +0.98 & -0.90 & & $19-3,53$ & +2.37 & +0.63 \\
\hline & $9-2,108$ & +1.23 & -0.90 & & $19-4,2$ & +2.14 & +0.67 \\
\hline \multirow[t]{12}{*}{75.0} & $9-3,20$ & +1.50 & -0.80 & & $19-5,53$ & +2.20 & +0.17 \\
\hline & $10-1,43$ & +1.16 & -0.80 & 136.0 & $20-1,100$ & +1.55 & -0.24 \\
\hline & $10-1,121$ & $\begin{array}{l}+1.28 \\
+1.28\end{array}$ & -0.76 & & $20-2,33$ & +1.48 & -0.11 \\
\hline & $10-2,30$ & +1.28 & -0.83 & & $20-2,100$ & +1.46 & +0.08 \\
\hline & $10-2,126$ & +0.73 & - & & $20-3,33$ & +2.10 & +0.35 \\
\hline & $10-3,70$ & +2.09 & -0.89 & & $20-3,100$ & +1.97 & +0.22 \\
\hline & $10-4,43$ & +2.85 & -0.68 & 141.0 & & & \\
\hline & $10-4,96$ & +1.20 & - & & & & \\
\hline & $10-4,114$ & +1.77 & -1.21 & & & & \\
\hline & $10-5,43$ & +0.93 & -0.82 & & & & \\
\hline & $10-6,56$ & +1.14 & -1.03 & & & & \\
\hline & $10-6,88$ & +1.27 & - & & & & \\
\hline
\end{tabular}

a $\delta^{18} \mathrm{O}$ and $\delta^{13} \mathrm{C}$ are referred to the international PDB. I standard.

Values are for N. pachyderma.

\section{Isotopic Stratigraphy}

The sampling interval, which ranges from 10 to $130 \mathrm{~cm}$ or more, is clearly too large to reveal the true climatic variability and too large to allow a precise identification and numbering of oxygen-isotope stages in the Pleistocene sequence. 
Table 2. Oxygen- and carbon-isotope analysis of $G$. bulloides and/or N. pachyderma from Hole 549A.

\begin{tabular}{|c|c|c|c|c|c|c|c|}
\hline $\begin{array}{l}\text { Depth below } \\
\text { seafloor } \\
\text { (m) }\end{array}$ & $\begin{array}{l}\text { Core-Section } \\
\text { (level in cm) }\end{array}$ & $\delta^{18} \mathrm{O}^{\mathrm{a}}$ & ${ }_{\delta}{ }^{13} \mathrm{C}^{\mathrm{a}}$ & $\begin{array}{l}\text { Depth below } \\
\text { seafloor } \\
\text { (m) }\end{array}$ & $\begin{array}{l}\text { Core-Section } \\
\text { (level in } \mathrm{cm} \text { ) }\end{array}$ & $\delta^{18} \mathrm{O}$ & $\delta^{13} \mathrm{C}$ \\
\hline & $1-1.8$ & +1.05 & -0.76 & & $2-5,10$ & +1.11 & -0.26 \\
\hline & $1-1,39$ & +1.87 & -0.37 & & $2-5,20$ & +2.65 & -0.29 \\
\hline & $1-1,137$ & +2.07 & -0.87 & & $2-5,80$ & +1.57 & -0.46 \\
\hline & $1-2,5$ & +1.81 & -1.54 & & $2-6,64$ & +1.93 & -1.35 \\
\hline & $1-2,130$ & +2.25 & -0.41 & 16.0 & $2-6,103$ & +2.36 & -0.73 \\
\hline & $1-2,70^{b}$ & +2.51 & -0.39 & & & & \\
\hline & & & & & $3-1,2$ & +1.57 & -0.23 \\
\hline & $1-3,10$ & +2.00 & -0.42 & & $3-1,89$ & +3.17 & \\
\hline & $1-3,20$ & +1.55 & -0.83 & & & & \\
\hline & $1-3,70$ & +2.58 & -0.85 & & $3-2,89$ & +2.80 & -0.22 \\
\hline & $1-3,125$ & +1.88 & -0.86 & & $3-2,115$ & +1.74 & -0.84 \\
\hline & & & & & $3-2,138$ & +1.83 & +0.25 \\
\hline & $1-4,20$ & +2.08 & -0.32 & & $3-2,147$ & +1.33 & +0.07 \\
\hline & $1-4,40$ & +2.56 & -0.60 & & & & \\
\hline & $1-4,54$ & +2.61 & +0.08 & & $3-3,39$ & +1.78 & -0.14 \\
\hline & $1-4,88$ & +2.88 & -0.99 & & $3-3,41$ & +2.10 & -0.73 \\
\hline & $1-4,100$ & +2.47 & -0.21 & & $3-3,70$ & +1.66 & -0.65 \\
\hline & & & & & $3-3,99$ & +1.04 & -1.00 \\
\hline & $1-5,20$ & +3.17 & -1.17 & & $3-4,1$ & +2.46 & -0.43 \\
\hline \multirow[t]{19}{*}{7.47} & $1-5,144$ & +1.64 & -0.76 & & $3.4,47$ & +3.00 & -0.95 \\
\hline & & & & & $3-4,64$ & +2.03 & -0.76 \\
\hline & $2-1,3$ & +2.16 & 0.00 & & $3-4,105$ & +2.65 & -0.87 \\
\hline & $2-1,10$ & +1.10 & -0.67 & & & & \\
\hline & $2-1,20$ & +1.43 & -0.25 & & $3-5,10$ & +3.23 & -0.43 \\
\hline & $2-1,55$ & +1.96 & -0.78 & & $3-5,16$ & +2.20 & -1.02 \\
\hline & $2-1,102$ & +1.51 & -1.03 & & $3-5,47$ & +1.44 & -0.82 \\
\hline & $2-1,135$ & +1.77 & -0.96 & & & & \\
\hline & & & & & $3-6,46$ & +1.76 & -0.55 \\
\hline & $2-2,20$ & +1.15 & -0.44 & & $3-6,80$ & +2.13 & -0.40 \\
\hline & $2-2,56$ & +2.27 & -0.79 & 27.0 & $3, \mathrm{CC}, 15$ & +2.10 & -0.67 \\
\hline & $2-2,95$ & +1.75 & -0.43 & & & & \\
\hline & $2-3,15$ & +2.77 & -0.79 & & & & \\
\hline & $2-3,20$ & +2.28 & -1.30 & & & & \\
\hline & $2-3,58$ & +1.27 & -0.49 & & & & \\
\hline & $2-3,93$ & +1.02 & -0.64 & & & & \\
\hline & $2-3,107$ & +0.28 & -1.01 & & & & \\
\hline & $2-3,132$ & +1.93 & -0.72 & & & & \\
\hline & $2-4,74$ & +2.37 & -0.97 & & & & \\
\hline
\end{tabular}

${ }^{2}{ }^{13} \mathrm{C}$ and $\delta^{18} \mathrm{O}$ are referred to the international PDB. 1 standard.

Values are for $N$. pachyderma.

\section{Identification of Oxygen-Isotopic Peaks}

An isotopic stratigraphy may be scaled in two different ways: (1) either by adjusting the stage numbering to the available paleomagnetic data or biostratigraphic data or (2) by identifying some isotopic stages, such as 5 , $7,12,13-15,16$, or 22 , on the basis of the pattern or intensity of the isotopic signal and then extrapolating the numbering between them.

\section{Site 548}

The available paleomagnetic scale for Site 548 cannot be correlated with the standard one; the reversed episode occurring between Sections 548-10-4 and 548-10-5 might be a true one or an artifact. The following normal period between Sections 548-10-5 and 548-11-3 could belong either to the Bruhnes or the Jaramillo Event. It is known that the Jaramillo paleomagnetic event brackets oxygen-isotope Stage 24. Therefore, Stage 24 should lie at the levels either between Sections 548-10-5 and 54811-3 or between Sections 548-12-1 and 548-13-2.

Furthermore, oxygen-isotope Stage 22 is characterized by a pronounced positive $\delta^{18} \mathrm{O}$ peak in all previously studied Atlantic cores. This allows subdivision of the Pleistocene into two sequences: a preglacial and a glacial one. A first hypothesis could be that the positive oxygen-isotope peak occurring at level 548-10-4, $43 \mathrm{~cm}$ may be Stage 22. If this is true, the underlying positive $\delta^{18} \mathrm{O}$ peak at level $548-11-2,140 \mathrm{~cm}$ would correspond to
Stage 24; consequently, the Jaramillo Event would be the first normal episode encountered down core, between Sections 548-10-5 and 548-11-3. Such an extrapolation, however, disagrees with the bioclimatic subdivisions and the benthic faunal data. Caralp (this volume) has shown that a significant decrease in the Pleurostomella-Stilostomella assemblages occurred in Hole 549A at the transition between isotopic Stages 16 and 17. At Site 548, this faunal change occurs in Core 10 (Section 4). Assuming that this decrease was synchronous at different water depths, one would conclude that the strong positive isotopic peak at 548-10-4, $43 \mathrm{~cm}$ may be Stage 16 . In that case the Jaramillo Event would be located between Sections 548-12-1 and 548-13-2, and Stage 22 (as well as older isotopic stages) cannot be identified on the $\delta^{18} \mathrm{O}$ curve. Isotopic Stages 13 and 15 , bracketed by isotopic Stages 12 and 16 (Sections 548-7-6 to 548-9-3), display a classic morphology with a less intense $\delta^{18} \mathrm{O}$ peak for glacial Stage 14. Thus numbering the upper 16 isotopic stages is straightforward.

The well-marked positive $\delta^{18} \mathrm{O}$ peak between levels $548-7-3,40 \mathrm{~cm}$ and $548-7-5,140 \mathrm{~cm}$ is identified as oxygen-isotopic Stage 12. This numbering is supported by the last appearance datum (LAD) of Pseudoemiliana lacunosa at about $60 \mathrm{~m}(548-7-5,140 \mathrm{~cm})$, at the top of oxygen-isotope Stage 13, an event dated at 470,000 yr. ago (Thierstein et al., 1977).

Upward extrapolation of stage numbering leads to the following identification:

\begin{tabular}{cc}
\hline $\begin{array}{c}\text { Oxygen-isotope } \\
\text { stage }\end{array}$ & Core-Section \\
\hline 11 & $7-2$ to $6-2$ \\
9 & $5-4$ to $4-6$ \\
7 & $4-3$ to $4-1$ \\
5 & $3-5$ to $3-1$ \\
\hline
\end{tabular}

It is not clear whether the most recent isotopic Stage 1 is missing or not. $\delta^{18} \mathrm{O}$ values measured at the top of the first core $(+2.2 \%)$ do not reflect the present-day value, which is about $+1 \%$ for $G$. bulloides. Below isotopic Stage $16(548-10-4,43 \mathrm{~cm})$, however, stage numbering is uncertain. According to van Donk's stratigraphy for Atlantic Core V16-205, the Olduvai Event (located here between Sections 548-15-1 and 548-15-6) should correspond to isotopic Stage 28. According to the Shackleton and Opdyke (1976) stratigraphy for Pacific Core V28239, the Olduvai Event should correspond to a higher number than isotopic Stage 40. These differences indicate that stage numbering is difficult for periods older than about 600,000 yr.

\section{Site 549 (Hole 549A)}

All isotopic stages that can be identified in Hole 549A belong to the Bruhnes magnetic epoch. In the deepest Pleistocene core (Core 3), two prominent positive $\delta^{18} \mathrm{O}$ peaks at 549A-3-5, $10 \mathrm{~cm}$ and 549A-3-1, $89 \mathrm{~cm}$ to 549A$3-2,89 \mathrm{~cm}$ are identifiable as oxygen-isotopic Stages 16 and 12 , respectively. Identification of Stage 12 is confirmed by the LAD of Pseudoemiliana lacunosa in Sec- 
tion 549A-3-2. Two glacial $\delta^{18} \mathrm{O}$ peaks are less pronounced: isotopic Stage 10 (levels 549A-2-5, $20 \mathrm{~cm}$ to 549A-2-4, $74 \mathrm{~cm}$ ) and isotopic Stage 8 (levels 549A-2-3, $20 \mathrm{~cm}$ to $549 \mathrm{~A}-2-3,15 \mathrm{~cm}$ ). Identification of isotopic Stage 8 is in good agreement with the nearly complete disappearance of Gephyrocapsa caribbeanica at the same depth (site chapter, this volume). Isotopic Stage 6 is identified between levels 549A-1-5, 70 and 549A-1-4, 54 $\mathrm{cm}$. Stage 2 is apparently not documented but should be located between 549A-1-1, $39 \mathrm{~cm}$ and 549A-1-1, $137 \mathrm{~cm}$, where no data are available.

This stratigraphy based on oxygen-isotopic variations displayed by planktonic foraminifers is in good general agreement with that deduced from benthic foraminifers (Fig. 5) (Vergnaud Grazzini and Saliège, this volume).

\section{Oxygen-Isotope Data}

At Site $548 \delta^{18} \mathrm{O}$ values range from $+0.5 \%$ for lower Pleistocene (interglacial values) to $+3.3 \%$ for upper Pleistocene (maximal glacial values). $\delta^{18} \mathrm{O}$ values higher than $2.5 \%$ were obtained at seven different levels in the sequence: $548-2-1,20 \mathrm{~cm}, 548-2-3,20 \mathrm{~cm}, 548-2-4,50 \mathrm{~cm}$, $548-3-1,34 \mathrm{~cm}, 548-10-4,43 \mathrm{~cm}, 548-15-5,92 \mathrm{~cm}$, and $548-17-7,50 \mathrm{~cm}$. On the whole, the oxygen-isotopic curve displays a decreasing trend from the bottom of the section to level $548-10-4,43 \mathrm{~cm}$, identified as isotopic Stage 16 (average $+1.6 \%$ ). Oscillations are of low amplitude and average about $1 \% 0 \delta^{18} \mathrm{O}$. Amplitudes of $\delta^{18} \mathrm{O}$ fluctuations are higher above level 548-10-4, $43 \mathrm{~cm}$ and average $1.7 \% 0 \delta^{18} \mathrm{O}$.

At Site 549 (Hole 549A) $\delta^{18} \mathrm{O}$ values range from minimal interglacial values of about $+1.0 \%$ to maximal glacial values of about $+3.2 \%$.

Thus, the overall $\delta^{18} \mathrm{O}$ change recorded by planktonic foraminifers in the upper Pleistocene sediments $(470,000$ yr. old or slightly more) of that part of the northeastern Atlantic is only 0.5 to $0.7 \%$ higher than the glacial-interglacial change in the oxygen-isotopic composition of the seawater-1.7\%0 - stated by some authors (Duplessy et al., 1980).

\section{Carbon-Isotope Data}

At Site $548, \delta^{13} \mathrm{C}$ values range from $+0.5 \%$ (recorded in Pliocene sediments) to $-1.5 \%$ (recorded in the level overlying Core 15). The carbon isotopic curve displays a general trend from high $\delta^{13} \mathrm{C}$ values in Pliocene sediments to lower $\delta^{13} \mathrm{C}$ values in Pleistocene sediments. This trend can be seen at least from Core 20 through Core 10. Amplitudes of $\delta^{13} \mathrm{C}$ variations are higher above Core 16.

At Site 549 (Hole 549A), $\delta^{13} \mathrm{C}$ values range from $-1.54 \%$ to $+0.25 \%$, with $80 \%$ of the values lying between $-0.2 \%$ and $-1.0 \%$ and an average value of about $-0.62 \%$, which is very close to that found at Site 548 for the same timespan. Furthermore, $\delta^{13} \mathrm{C}$ values display oscillations of large amplitude $(\geq 1.0 \%)$.

\section{Paleoenvironmental Changes in Surface Waters}

Glacial-interglacial cycles in the northeastern Atlantic are characterized by north-south water mass movements that can be reconstructed from foraminiferal as- semblages. In this way Ruddiman and McIntyre (1976) have delineated the regional distribution of water masses at different times for the Quaternary period. The evolution of water masses at Sites 549 and 548 through the whole Pleistocene can be reconstructed from stable isotopic changes in planktonic foraminiferal shells and foraminiferal assemblage compositions. Climatic extremes that emerge from such a study may be tentatively compared to the different climatic situations depicted by Ruddiman and McIntyre (1976).

From the Pliocene to the Bruhnes-Matuyama transition, $\delta^{18} \mathrm{O}$ minima of interglacial episodes decrease from a value of $+1.5 \%$ in the Pliocene to a value of $+0.5 \% 0$ before Stage 16 (Sections 548-11-4 and 548-11-3). After Stage 16, interglacial $\delta^{18} \mathrm{O}$ values rapidly increase again to an average value of $+1.0 \%$ above Section $548-8-4$ (isotopic Stage 13).

Among the different scenarios outlined by Ruddiman and McIntyre (1976), the interglacial peak at $125,000 \mathrm{yr}$. ago can be characterized by warm water masses dominating temperate latitudes (Fig. 4); warm subtropical waters penetrated northward as far as $55^{\circ} \mathrm{N}$ latitude "in response to this unusual warmth." The present-day interglacial is characterized by the dominance of transitional water masses. When compared with the last glacial and 125,000-year-old interglacial climatic extremes, present conditions lie 75 to $80 \%$ closer to the warm extreme of Pleistocene glacial-interglacial conditions. One might therefore speculate that during full Pleistocene interglacial periods, subtropical water masses dominated at the latitude of Sites 548 and 549. Furthermore, the $1 \%_{0} \delta^{18} \mathrm{O}$ difference observed between different interglacial maxima may reflect temperature differences of as much as $4^{\circ} \mathrm{C}$. This difference may result from varying influxes of subtropical waters through the Gulf Stream gyre. From the Pliocene to the early Pleistocene (between about 600,000 and 750,000 yr. ago), the northward extension of the Gulf Stream gyre increases in successive interglacial phases, and Sites 548 and 549 were occupied by subtropical water masses that might have been warmer than what is inferred for more recent interglacial extremes. This geographical distribution of water masses does not appear to be related to velocity excursions of the Gulf Stream reported for the late Pliocene (2.9-2.3 m.y. ago) and late Pleistocene (1.5-0.0 m.y. ago), also related to global climate events, and inferred from sedimentary hiatuses of the Blake Plateau (Kaneps, 1979). Pleistocene and Pliocene time, however, considered as a whole was characterized by higher current velocity, and there has been a general strengthening of the Gulf Stream since the late Miocene, related mostly to tectonic events.

A true glacial mode is recorded only from isotopic Stage 16 at Site 548; prior to that time, with only a few exceptions (Sections 548-17-5 or 548-15-4 and 548-15-5), glacial maxima are less intense. Although bioturbation might have smoothed the isotopic and faunal records, this subdivision of the Pleistocene might be a real one. It is also recorded by benthic foraminifers. Intense glacial maxima of the upper Pleistocene, which have been extensively documented in the literature, are characterized by the southward penetration of polar waters with 


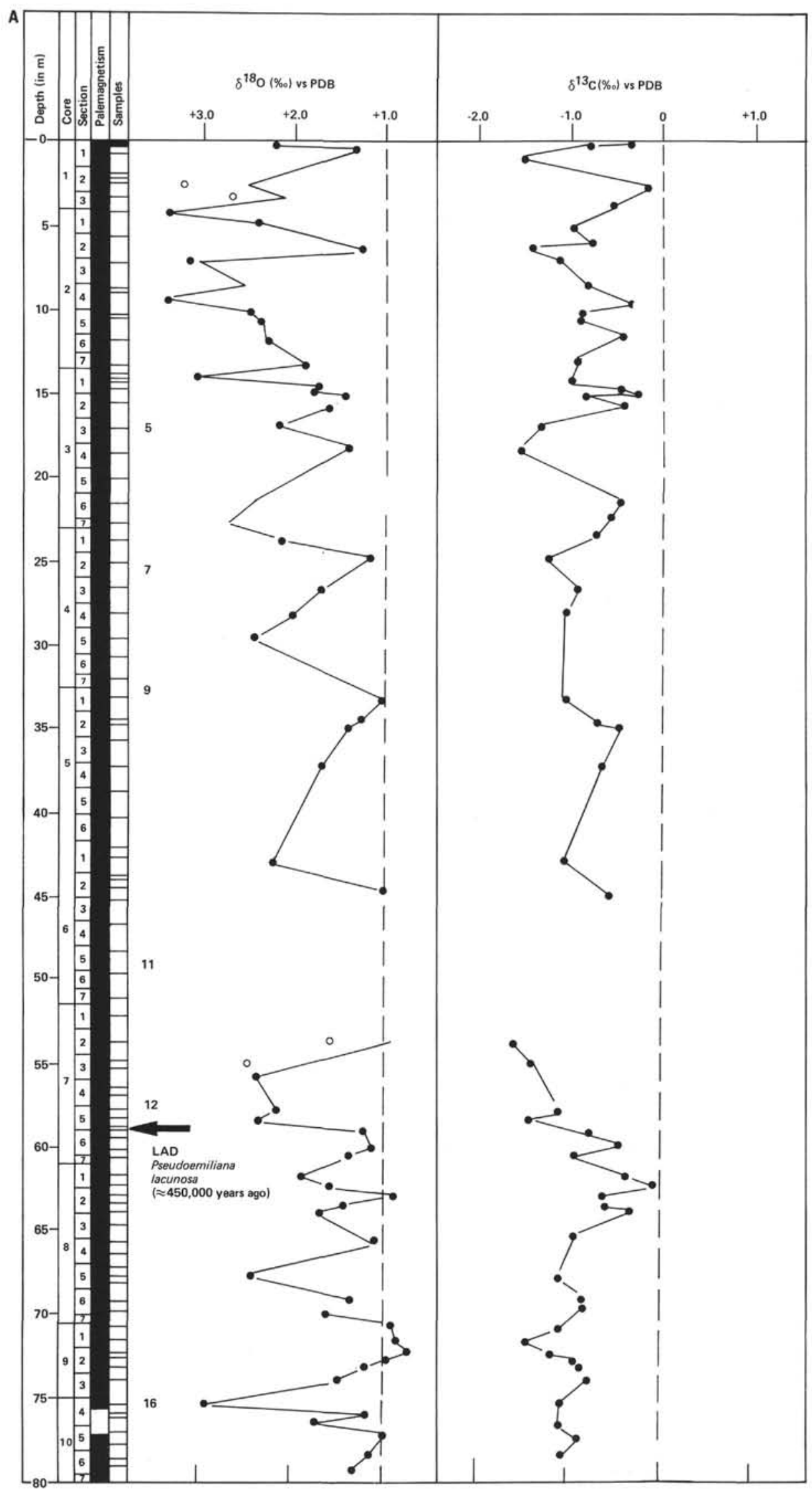

Figure 3. Oxygen- and carbon-isotopic variations in Globigerina bulloides (solid circles) and Neogloboquadrina pachyderma (open circles) against depth at Site 548. A. Cores 1 to 10. B. Cores 11 to 20 . 


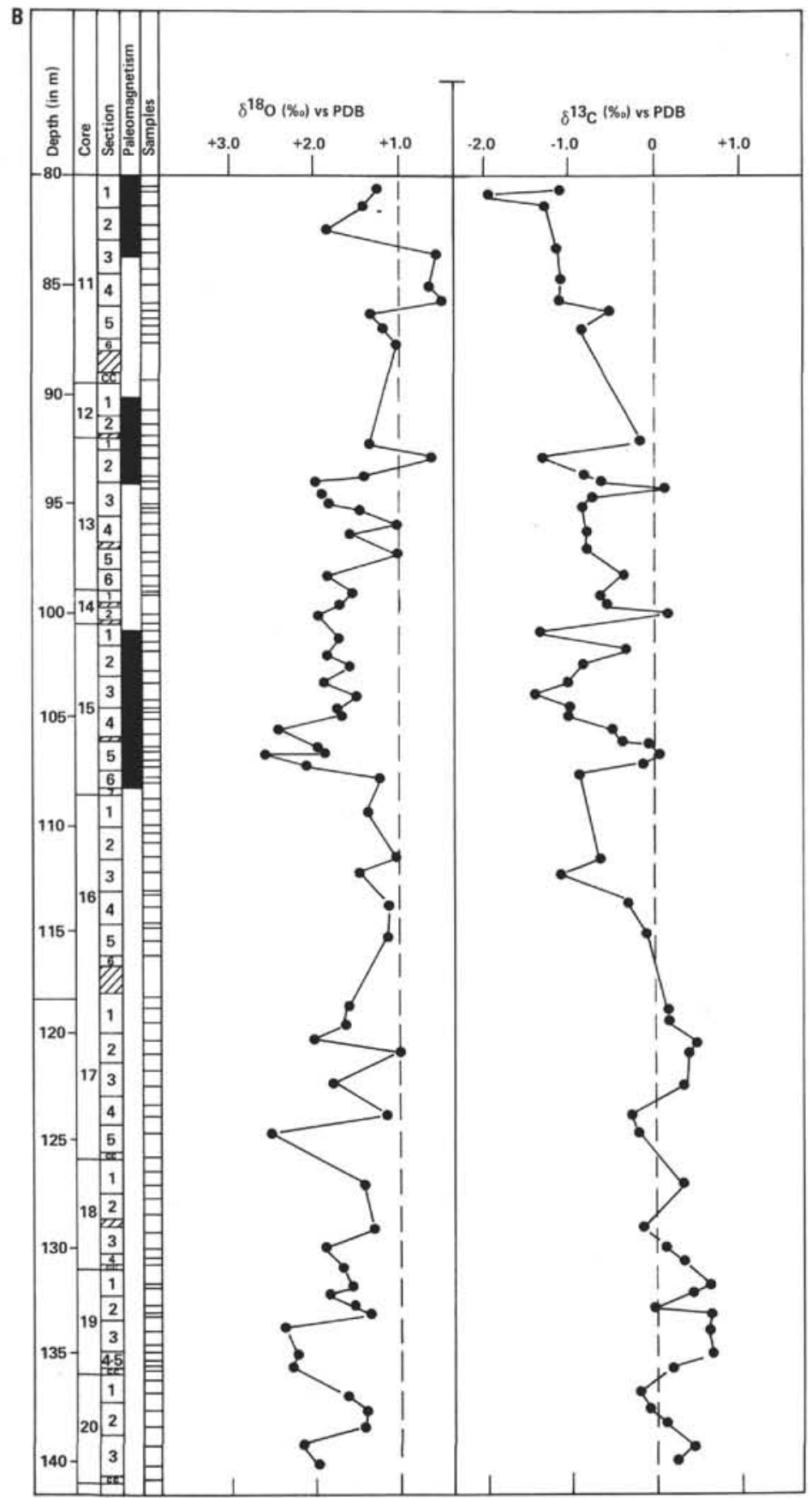

Figure 3. (Continued).

dominant ( $>95 \%$ ) left-coiling Neogloboquadrina pachyderma. At Site 548, a trend can be observed through the Pleistocene: in the lower Pleistocene, up to isotopic Stage 12 (Sections 548-7-4 to 548-7-2), increased percentages of this species can be seen at four places. The lowest percentages are recorded during the Olduvai Event (between 30 and $40 \%$ ), and higher percentages are recorded close to isotopic Stage $12(\sim 70 \%)$. Southward penetration of the polar microfauna is found in the following sections: $548-15-4$ to $548-15-1$ (in Olduvai), 54814-2 to 548-13-1, 548-10-6 to 548-10-4 (close to isotopic Stage 16), 548-8-7 to 548-8-5 (close to isotopic Stage 14), and 548-7-5 to 548-7-1 (close to isotopic Stage 12).
The upper Pleistocene from Stage 12 upward is better recorded at Site 549 (Hole 549A). Southward excursions of the polar faunas, dominated by the left-coiling $N$. pachyderma, are more frequent, and percentages of this last form are higher and range from 85 to $95 \%$. They correspond to isotopic Stage 12 (Sections 549A-3-2 to 549A-3-1), isotopic Stage 10 and part of 11 (Sections $549 \mathrm{~A}-2-4$ to $549 \mathrm{~A}-2-5$ ), isotopic Stage 6 (Section 549A1-5), and isotopic Stage 2 (Sections 549A-1-2 to 549A-11). Thus, the overall Pleistocene faunal record at Sites 548 and 549 indicates that polar water masses might have shifted south of latitude $50^{\circ} \mathrm{N}$ at eight different times. At these times a cold counterclockwise gyre en- 


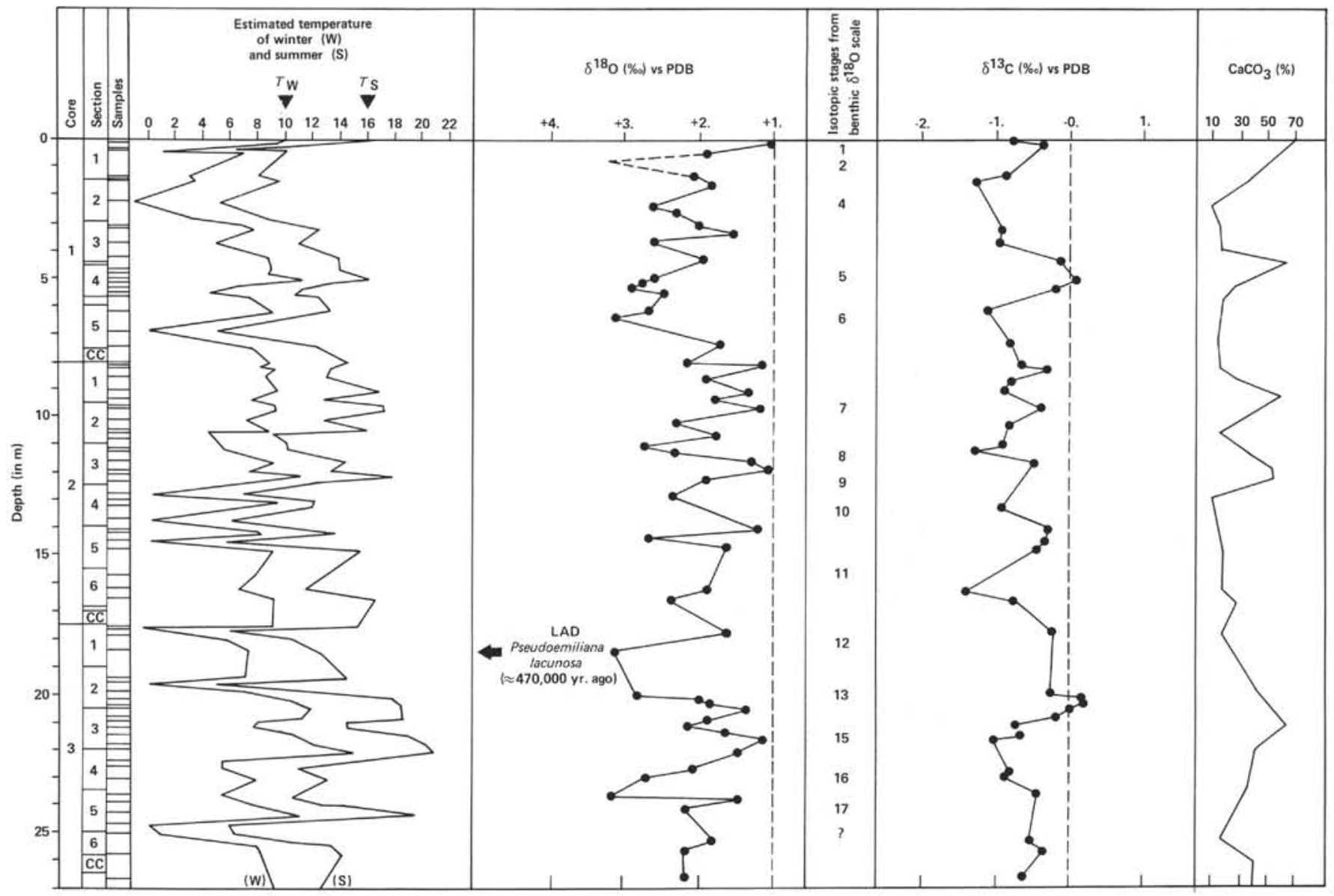

Figure 4. Oxygen- and carbon-isotopic variations of G. bulloides plotted against depth at Hole 549A. Winter and summer estimated temperatures in superficial waters are reported on the left and $\mathrm{CaCO}_{3}(\%)$ on the right (after Pujol and Duprat, this volume). Isotopic stage numbering is deduced from benthic foraminiferal isotopic stratigraphy (from Vergnaud Grazzini and Saliège, this volume).

veloped the North Atlantic above latitude $45^{\circ} \mathrm{N}$, and subpolar and transitional waters were essentially eliminated by being compressed into a narrow band between the clockwise subtropical gyre and the counterclockwise polar gyre.

These episodes are also times of well-marked $\delta^{18} \mathrm{O}$ maximal peaks on the isotopic curve: Stages 16, 12, 10, 6 , and 2. The Olduvai might also have corresponded to a slight southward penetration of the polar faunas, but percentages of left-coiling $N$. pachyderma are relatively low $(30-40 \%)$. This might imply that glacial episodes prior to isotopic Stage 12 were not as intense as the most recent ones.

Furthermore, the incomplete sediment recovery does not permit a clear assessment of whether true glacial modes associated with southward excursions of the Polar Front down to $42^{\circ} \mathrm{N}$ latitude started at the time of isotopic Stage 12 or before, at the time of oxygen isotopic Stage 16. Isotopic Stage 12 is known as a time of important faunal changes in the northeastern Atlantic, and the first hypothesis might be the most plausible one.

It also appears that water mass movements were not identical across the various climatic cycles of the Pleistocene and that Pleistocene climatic changes followed a quite different pattern before about 600,000 years ago. The now classic glacial-interglacial $\delta^{18} \mathrm{O}$ changes can be clearly seen after isotopic Stage 16 .

\section{Surface Paleotemperature Changes in the Late Pleistocene}

Sea-surface temperature changes deduced from transfer-function estimates (Pujol and Duprat, this volume) average 10 to $12^{\circ} \mathrm{C}$ between glacial and interglacial phases. This change is in good agreement with other estimates previously published that are also based on faunal analyses (Ruddiman and McIntyre, 1981). A 10 to $12^{\circ} \mathrm{C}$ temperature change should have resulted in a 2.4 to $2.85 \%_{0} \delta^{18} \mathrm{O}$ change in marine carbonates, which should be added to a change in the isotopic composition of seawater $\left(\delta_{w}\right)$. Thus the overall $\delta^{18} \mathrm{O}$ change recorded by Globigerina bulloides between glacial and interglacial phases, which is around $2.2 \%$, could have resulted from a variety of factors: (1) a strong bioturbation effect, (2) a change in the oxygen-isotopic composition of seawater that is different from the global ice volume effect postulated by various authors $(+1.7 \%)$, or (3) a change in $G$. bulloides ecology. 


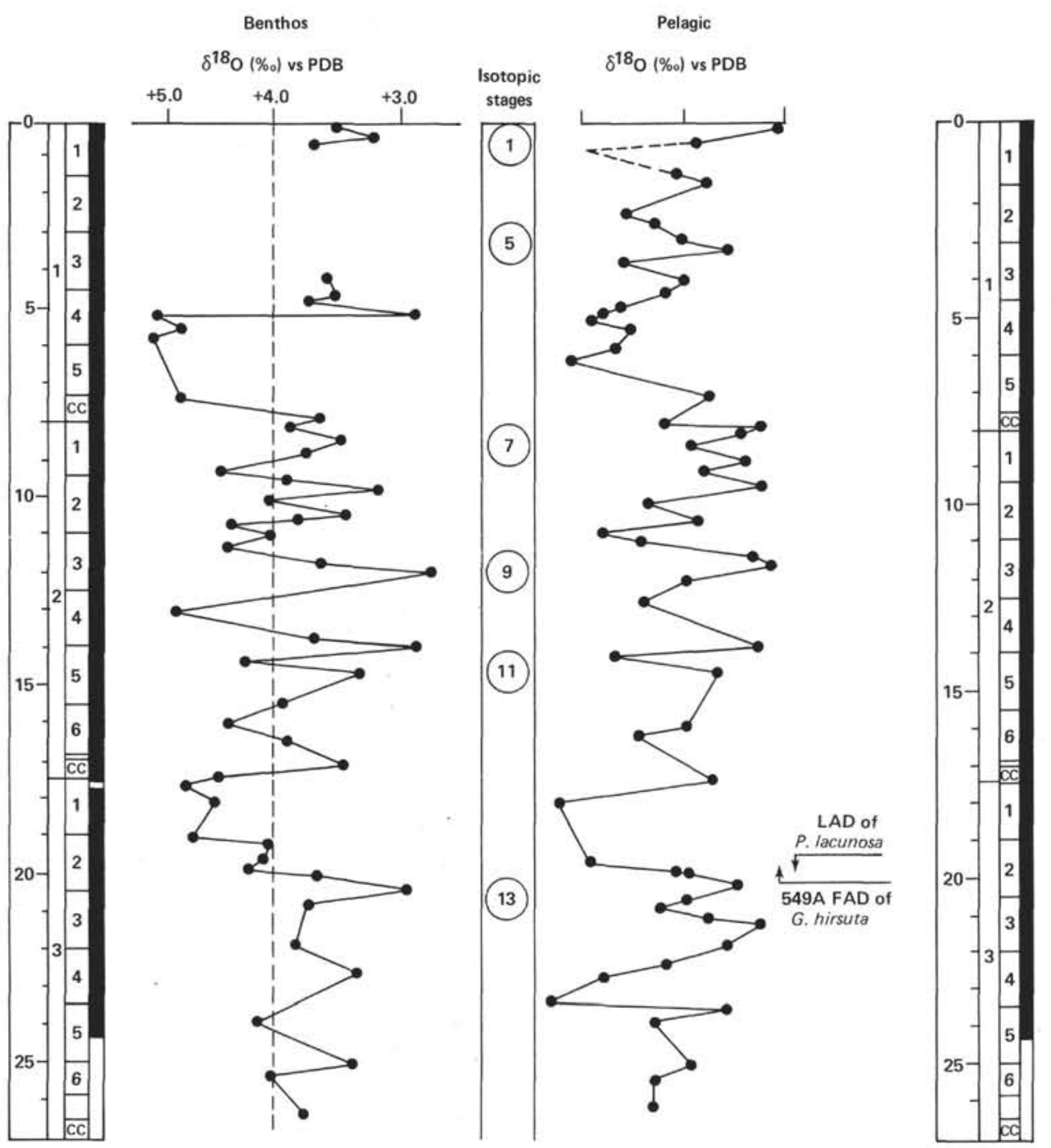

Figure 5. A comparison between oxygen-isotopic stratigraphies deduced from G. bulloides and Cibicides analyses for Hole 549A (water depth $2535 \mathrm{~m}$ ).

\section{Bioturbation Effect}

In some cases, bioturbation has been used to explain smoothing of isotopic curves. It could also explain the fact that at Sites 548 and 549 polar faunas do not correspond to $100 \%$ of left-coiling Neogloboquadrina pachyderma but only to 85 to $95 \%$. Thus bioturbation could be responsible for 5 to $15 \%$ mixing of the assemblage. Attempts have been made to restore the original unmixed record from mixed isotopic records (Berger and Heath, 1968; Berger et al., 1977), but it is necessary to know the exact mixing intensity. Jones and Ruddiman (1982) have shown that the deconvolution operation is not easy to apply. In particular, variations in the abundance of foraminiferal species can create artificial leads and lags in isotopic signals. If a species being analyzed for $\delta^{18} \mathrm{O}$ is more abundant in interglacial than in glacial sediments, even with deconvolution of the correct mixedlayer thickness and with no analytical error, a "melt-water spike" $\left(\delta^{18} \mathrm{O}\right.$ negative peak) will be created where none exists if abundance variations are not included.
The species analyzed here, Globigerina bulloides, varies from 20 to $40 \%$ during interglacial times to a few percent during glacial times. This does not allow the reconstruction of the initial true isotopic record. Thus any conclusion concerning leads and lags between isotopic signals in deep water (i.e., ice volume changes), surface water, or sea surface temperatures estimated through transfer function are unreliable.

\section{Oxygen Isotopic Changes in Seawater}

The change in the surface water $\delta^{18} \mathrm{O}$ at Sites 548 and 549 may have been of a smaller amplitude than that of the global ice volume effect because of water mass migrations and/or the proximity of the northern ice cap. Assuming that Globigerina bulloides $\delta^{18} \mathrm{O}$ changes reflect the whole glacial-interglacial temperature change of about 10 to $12^{\circ} \mathrm{C}$ (equivalent to $2.4-2.85 \% 0 \delta^{18} \mathrm{O}$ ), it follows that the $2.2 \% 0 \delta^{18} \mathrm{O}$ change recorded by this species implies that the oxygen isotopic composition of glacial surface waters was $-0.2 \%$ to $-0.65 \%$ lighter than at present. This in turn suggests a layering of water mass- 
es quite similar to that exhibited today by the various arctic basins or the East Greenland Current (Coachman and Aagaard, 1974) (Fig. 6). Polar or arctic waters extend from the surface down to a depth of 200 or $150 \mathrm{~m}$, with temperatures varying between the freezing point (in the upper layers during winter) and $0^{\circ} \mathrm{C}$. Normally a strong halocline is present, with the salinity at the surface being less than $30 \%$ but reaching values of $34 \%$ at the bottom of the polar or arctic waters. Assuming a glacial salinity about 3.5\% higher than today (Broecker, 1982), polar or arctic water salinities for the glacial period would have been 33.5 to $37.5 \%$. The salinity value of $33.5 \%$ is agreeable with a $\delta^{18} \mathrm{O}$ value for the water of about -0.4 to $-0.5 \%$. This is in good agreement with the $2.2 \% 0 \delta^{18} \mathrm{O}$ change recorded by $G$. bulloides for the period between the interglacial and glacial phases. The same oceanographic structure has been postulated for glacial winters from stable isotope analyses of benthic foraminifers (Vergnaud Grazzini and Saliège, this volume).

\section{A Change in Globigerina bulloides Temperature Requirements}

An apparent change in temperature requirements can actually represent a change in the depth habitat or in the season of maximal occurrence. A change in depth habitat for a surface dwelling species in order to adjust to warmer temperatures makes sense if a strong thermocline exists in surface or subsurface waters. This might have been the case in a two-layered system, as described above. A change in the season of maximal occurrence could be related, for instance, to a change in "peak seasons" for nutrients, oxygen, and other factors. Although such alternatives are mere speculations, the low amplitudes of the $\delta^{18} \mathrm{O}$ variations recorded by $G$. bulloides may well be the result of a combination of two or three of the influences suggested above.

\section{Carbon Isotopic Changes}

The most striking feature of the carbon-isotope record is that average $\delta^{13} \mathrm{C}$ values recorded by $G$. bulloides are higher in the upper Pliocene sediments than in younger deposits. Up to Core $548-16, \delta^{13} \mathrm{C}$ values average 0 to $+0.4 \%$; they then decrease by steps to $-0.6 \%$ (Cores 16 to 15 ), $-0.7 \% 0$ (Cores 14 to 8 ), and $-0.9 \%$ (Cores 7 to 1$)$.

The steep $1 \% 0$ decrease that occurs just below the Olduvai level may reflect the warm surface waters before that time. The waters were warmer because of a more northward extension of the Gulf Stream gyre. In warm waters $\mathrm{CO}_{2}$ solubility decreases, and total dissolved inorganic carbon is enriched in the heavy-carbon isotope because of the departure of light $\mathrm{CO}_{2}$. Warm subtropical waters can also be responsible for low $\delta^{18} \mathrm{O}$ values of interglacial foraminifers. According to this interpretation, however, one would expect a better correlation between $\delta^{13} \mathrm{C}$ and $\delta^{18} \mathrm{O}$ records: the $\delta^{18} \mathrm{O}$ record suggests an increasing northward influence of the Gulf Stream gyre prior to isotopic Stage $16(\sim 600,000$ years ago), while $\delta^{13} \mathrm{C}$ values start to decrease much earlier, before the Olduvai Event.

\section{CONCLUSIONS}

Late Pleistocene glacial-interglacial cycles are well recorded by oxygen-isotope ratio changes in Globigerina bulloides from northeastern Atlantic Sites 548 and 549, down to isotope Stage 16. Older isotopic stages cannot be uniquely identified on the oxygen-isotope curve. Nevertheless, some general trends appear that may be related to different fluxes or to a northward extension of subtropical waters brought by the Gulf Stream gyre or to both. From the Pliocene up to isotopic Stage 16, interglacial surface temperatures increased; they decreased in the late Pleistocene (Site 548). This long-term change

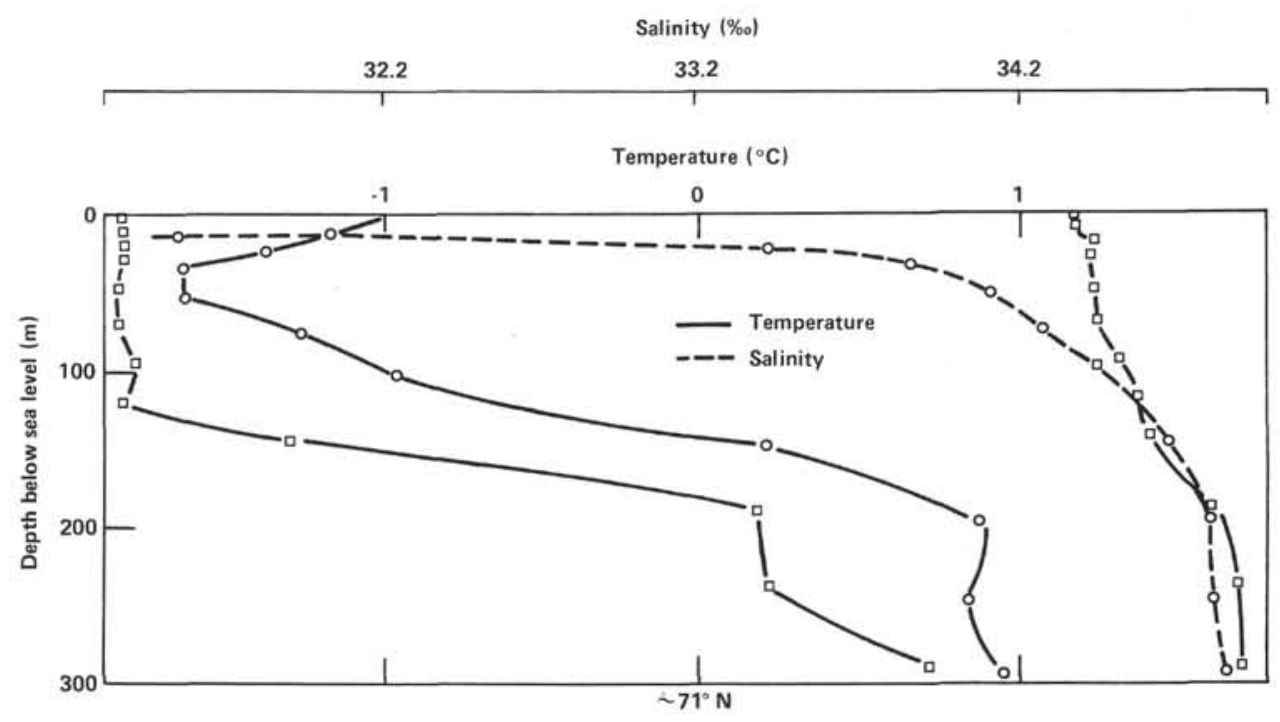

Figure 6. Temperatures and salinities at two stations located in the upper $300 \mathrm{~m}$ of the East Greenland Current (from Coachman and Aagaard, 1974). Circles indicate " 5 Edisto, 1965, 8-22" station, and squares indicate " 352 Arlis II, 4-5" station (their terminology). 
may be related to various northward extensions of the subtropical waters. Glacial maxima are more intensively recorded in the oxygen-isotope ratios from the last 470,000 yr. than from before. Important shifts in the geographic distribution of water masses have occurred in the northeastern Atlantic when passing from glacial maxima to interglacial minima.

Warmer waters of the late Pliocene favored the removal of light $\mathrm{CO}_{2}$, which is reflected in the higher $\delta^{13} \mathrm{C}$ values of the carbonates. This may be related to major fluxes of the Gulf Stream at that time.

\section{ACKNOWLEDGMENTS}

The writers wish to thank the Deep Sea Drilling Project for having made Leg 80 Quaternary samples available for the present study. The Laboratoire de Géologie Dynamique of Pierre et Marie Curie University (Paris 5ème) provided laboratory facilities and technical help; thanks are extended to M. J. Urrutiaguer for preparing samples for analyses. We are grateful to Dr. S. Savin for constructive criticisms and to Dr. W. Berggren and Prof. R. Letolle for helpful reviews of the manuscript. Research was supported by Centre National de la Recherche Scientifique through ERA 604 and ATP grant "Geology and Geophysics of the Oceans."

\section{REFERENCES}

Berger, W. H., and Heath, G. R., 1968. Vertical mixing in pelagic sediments. J. Mar. Res., 26:134-142.

Berger, W. H., Johnson, R. F., and Killingley J. S., 1977. "Unmixing" of the deep sea record and the deglacial meltwater spike. Nature (London), 269:661-663.

Broecker, W. S., 1982. Glacial to interglacial changes in ocean chemistry. Prog. Oceanog., 11:151-197.

Broecker, W. S., and van Donk, J., 1970. Insolation changes, ice volumes, and the ${ }^{18} \mathrm{O}$ record in deep-sea cores. Rev. Geophys. Space Phys, 8:169-191.

Cifelli R., and McCloy, C., 1983. Planktonic foraminifera and euthecosomatus pteropods in the surface waters of the North Atlantic. J. Foramin. Res., 13:91-107.
Coachman, L. K., and Aagaard, K., 1974. Physical oceanography of arctic and subarctic seas. In Herman Y. (Ed.), Marine Geology and Oceanography of the Arctic Seas: New York (Springer Verlag), pp. 1-72.

Duplessy, J. C., 1972. La géochimie des isotopes stables du carbone dans la mer [Thèse de Doctorat d'Etat]. Université Pierre et Marie Curie, Paris.

Duplessy, J. C., Moyes, J., and Pujol, C., 1980. Deep water formation in the North Atlantic Ocean during the last ice age. Nature (London), 286:479-482.

Jones, G. A., and Ruddiman, W. F., 1982. Assessing the Global Meltwater Spike. Quat. Res., 17:148-172.

Kaneps, A. G., 1979. Gulf Stream: velocity fluctuations during the Late Cenozoic. Science, 204:297-301.

Pujol, C., 1980. Les foraminifères planctoniques de l'Atlantique Nord au Quaternaire. Ecologie, stratigraphie, environnement. Mem. Inst. Geol. Bassin Aquitaine, 10:254.

Ruddiman, W. F., and McIntyre A., 1976. Northeast Atlantic paleoclimatic change over the past 600,000 years. In Cline, R. M., and Hays, J. D. (Eds.), Investigation of late Quaternary Palaeoceanography and Palaeoclimatology, Mem. Geol. Soc. Am., 145: 111-146.

1981. The North Atlantic Ocean during the last deglaciation. Palaeogeogr. Palaeoclimatol. Palaeoecol., 35:145-214.

Shackleton, N. J., and Opdyke, D., 1976. Oxygen isotope and palaeomagnetic stratigraphy of equatorial Pacific cores V28-239, late Pliocene to latest Pleistocene. In Cline, R. M., and Hays, J. D. (Eds.), Investigation of late Quaternary Palaeoceanography and Palaeoclimatology, Mem. Geol. Soc. Am., 145:443-464.

Thierstein, H. R., Geitzenauer, K., Molfino, B., and Shackleton, N. J., 1977. Global synchrometry of late Quaternary coccolith datums: validation by oxygen isotopes. Geology, 5:400-404.

van Donk, J., 1976. ${ }^{18} \mathrm{O}$ record of the Atlantic Ocean for the entire Pleistocene epoch. In Cline, R. M., and Hays, D. (Eds.), Investigation of late Quaternary Palaeoceanography and Palaeoclimatology, Mem. Geol. Soc. Am., 145:147-163.

Williams, D. F., Sommer, M. A., II, and Bender, M. L., 1977. Carbon isotopic compositions of recent planktonic foraminifera of the Indian Ocean. Earth Planet. Sci. Lett.; 36:391-403.

Date of Initial Receipt: July 28, 1983

Date of Acceptance: December 13, 1983 